\title{
CARLOS MARIGHELLA: ENTRE (DES)ENCONTROS COM LENIN
}

\author{
CARLOS MARIGHELLA: ENTRE (DES)ENCUENTROS CON LENIN
}

\section{CARLOS MARIGHELLA: IN DISAGREEMENTS WITH LENIN}

DOI: http:/ /dx.doi.org/10.9771/gmed.v12i2.38391

Edson Teixeira da Silva Júnior ${ }^{1}$

Resumo: A trajetória política de Carlos Marighella, correlacionada com algumas referências leninistas, é o eixo do presente trabalho. Dentro de alguns parâmetros do Partido Comunista Brasileiro (PCB), examinamos como aquele dirigente - em especial na década de 1960 - formulou a sua crítica a aliança com a burguesia no debate sobre a revolução brasileira, tendo como referência alguns escritos de Lenin.

Palavras-chave: Marighella. Lenin. Comunismo. Revolução.

Resumen: La trayectoria política de Carlos Marighella, correlacionada con algunas referencias leninistas, es el eje del presente trabajo. Dentro de ciertos parámetros del Partido Comunista Brasileño (PCB), examinamos cómo ese dirigente, especialmente en la década de 1960, formuló su crítica a la alianza con la burguesía en el debate sobre la revolución brasilera, teniendo como referencia algunos escritos de Lenin.

Palabras clave: Marighella. Lenin. Comunismo. Revolución.

Abstract: The political trajectory of Carlos Marighella, correlated with some Leninist references, is the axis of this work. Within some parameters of the Brazilian Communist Party (PCB), we examine how that leader - especially in the 1960s - formulated his criticism of the alliance within the debate about the Brazilian revolution, having as reference some Lenin's writings.

Keywords: Marighella. Lenin. Communism. Revolution.

Este artigo propõe analisar a trajetória política de Carlos Marighella no Partido Comunista Brasileiro $(\mathrm{PCB})^{2}$ destacando a correlação desenvolvida com alguns referenciais teóricos leninistas. Nesse sentido, em linhas gerais, analisamos alguns parâmetros que demarcaram o PCB - com a premissa inequívoca de sua autonomia diante do movimento comunista internacional. Em seguida, examinamos a inflexão política que Marighella passou a defender, na década de 1960, criticando a aliança com a burguesia e justificando sua adesão a guerrilha revolucionária. Simultaneamente, procuramos reter as interlocuções de Marighella sobre Lenin.

Carlos Marighella integrou o partido comunista entre 1934 e 1967. A rigor, com a implantação da Ditadura Empresarial-Militar (1964-1985), manifestou, publicamente, suas divergências. Nesse embate, liderou com Joaquim Câmara Ferreira - entre outros dirigentes e militantes - a formação de uma dissidência do partido que deu origem a Ação Libertadora Nacional (ALN), que preconizava a guerrilha 
como forma de resistência à ditadura. Em 4 de novembro de 1969, aos 58 anos de idade, Marighella foi assassinado pela ditadura numa estúpida emboscada ocorrida em São Paulo.

Nesse processo de crítica ao PCB e formação da ALN, entre outros temas, evidencia-se uma contribuição do referencial teórico leninista, que conduziu Carlos Marighella a defender uma insubordinação à aliança com a burguesia como um elemento central.

\title{
O PCB, Marighella e o "desencontro" com alguns referenciais leninistas
}

Entre 25 e 27 março de 1922, na cidade de Niterói, no Rio de Janeiro, realizou-se o Congresso de fundação do Partido Comunista Brasileiro. Konder previne que "o PCB não foi criado pela IC [Internacional Comunista]: foi criado por gente que atuava no nosso país, que se orientava em função da nossa realidade" (KONDER, 2009, p.166). E, ainda: "os dirigentes e ativistas da nova agremiação provinham da militância anarcossindicalista. (...) Praticamente, todos eles eram mal informados a respeito das concepções de Marx, tinham noções extremamente vagas de marxismo" (Ibidem, p.168).

Em 1924, houve o reconhecimento e a integração a Internacional Comunista. A partir de 1928, com a progressiva emergência de Josef Stalin, o VI Congresso da Internacional aprovou uma estratégia política "etapista" que teve longa repercussão sobre o PCB:

\begin{abstract}
A partir de uma visão demasiado esquemática e "etapista", os dirigentes da IC [Internacional Comunista] orientavam os partidos comunistas (PCs) dos países periféricos a estabelecerem alianças com a burguesia "nacionalista" e/ou a pequena burguesia, com vistas à formação de frentes políticas capazes de lutar contra o "imperialismo" e o "feudalismo"/latifúndio. Desde a segunda metade da década de 1920, com exceção do breve interregno 1928-1934, essa foi a estratégia adotada pelos agrupamentos comunistas de linha estalinista nos países "coloniais" e "semicoloniais" ao longo do século XX, com destaque para o Oriente e para a América Latina (DEMIER, 2017, p. 136).
\end{abstract}

Para Anita Prestes, “tal esquema se manteve durante décadas da história do PCB. Na prática, o PCB passou a ser um partido nacional-libertador" (PRESTES, 2017, p. 147). Essa tendência se ampliou com "uma interpretação esquemática, derivada do reducionismo stalinista e aqui em grande parte reproduzida pelo Partido Comunista do Brasil (PCB) entre os anos 1920 e 1960" (MATTOS, 2017, p.17). Contudo, o PCB não deve ser compreendido como uma organização subserviente aos ditames da IC, sua autonomia foi preponderante (VIANNA, 1992).

A vivência de Carlos Marighella no PCB pode ser assim sintetizada: "nas três décadas de sua militância política que antecederam ao golpe militar de 1964, Marighella mostrara-se um disciplinado e devotado militante e dirigente político do partido dos comunistas brasileiros" (FERREIRA, 2013, p.2). Em novembro de 1935, foi transferido da Bahia para o Rio de Janeiro, atuando na Comissão Especial de organização do Comitê Central, órgão destacado do partido. Em seguida, num contexto de perseguição aos comunistas devido a Insurreição de 1935, liderada pela Aliança Nacional Libertadora (ANL), "passou a gerenciar a produção gráfica (panfletos, folhetos, cartazes) do núcleo central do PCB" (MAGALHÃES, 2012, p.90). Foi preso três vezes na década de 1930: a primeira, na Bahia, por participação em 
mobilizações estudantis, em 1932; a segunda, em maio de 1936, no Rio de Janeiro, quando resistiu bravamente as torturas. Em 1938, Marighella passou a atuar em São Paulo, “chegou como secretário de Propaganda e logo ascendeu a número um no Estado" (Ibidem, p.107). Além disso, "coordenou a produção de folhetos contra Leon Trotsky e seus seguidores" no país (Ibid., p.108), fato que reafirma o alinhamento com o Partido Comunista soviético. A terceira, ocorreu em maio de 1939. Dessa vez, esteve preso na ilha de Fernando de Noronha, sendo transferido depois para a Ilha Grande. Anistiado no primeiro semestre de 1945, no mesmo ano, foi eleito deputado constituinte pela Bahia com 5.187 votos, junto com mais 13 deputados federais e um senador, Luís Carlos Prestes. O Partido Comunista avançava com mais de 100 mil filiados.

No parlamento, teve atuação destacada: “interveio 195 vezes no plenário. Foram 47 apartes, 39 discursos e dezessete requerimentos" (Ibidem, p.176). A atividade parlamentar foi examinada em artigo em que avalia a participação dos comunistas no congresso constituinte. Engels e sua análise sobre a importância do sufrágio universal na Europa, durante o século XIX, foi destacado:

O sufrágio universal trouxe, portanto, ao proletariado um grande benefício, que, quando mais não fosse, pelo menos, como diz Engels, abriu à nossa representação no Parlamento uma tribuna do alto da qual podemos falar a seus adversários, na Câmara, e às massas, fora dela, com uma autoridade e uma liberdade muito diferente das que tem na imprensa e nos comícios (MARIGHELLA, 1946 apud PINHEIRO; FERREIRA, 2013, p. 32) 3 .

Lenin também foi citado: “a luta na tribuna parlamentar é obrigatória para o partido do proletariado revolucionário, a fim de educar os elementos atrasados de sua classe, despertar e instruir a massa aldeã analfabeta, ignorante e "embrutecida" (Ibidem, p. 33). Com isso, Marighella defendia a luta parlamentar e extraparlamentar como não excludentes, mas complementares. $\mathrm{O}$ fato do partido comunista participar do processo constitucional não era uma vitória definitiva, ainda mais no limitado e coercitivo sistema representativo brasileiro.

Em $1^{\circ}$ de maio de 1946, Marighella escreveu num artigo: "ligados às massas, senhor de uma tática e estratégia acertada, apoiado firmemente no marxismo-leninismo, o PCB é hoje, na verdade, o único partido nacional existente” (MARIGHELLA, 1946 apud PINHEIRO; FERREIRA, 2013, p. 35)4. Resta indagar: a qual marxismo-leninismo o comunista baiano se referia? Certamente, mediado pela hegemonia de Stalin e os enfrentamentos da conjuntura brasileira.

Um debate que emergiu no parlamento questionava o vínculo do partido como Seção da Internacional Comunista. Após a Segunda-Guerra Mundial (1939-1945), a Guerra Fria reforçou a vassalagem do governo de Eurico Gaspar Dutra (1946-1951) aos Estados Unidos da América. Para os comunistas, tal aproximação implicou em perseguição implacável: em 7 de maio de 1947, o PCB teve o seu registro cassado. Em outubro de 1947, o governo Dutra rompeu relações diplomáticas com a exUnião Soviética. Em janeiro de 1948, cassaram o mandato de todos os comunistas eleitos pela legenda do PCB. O anticomunismo tinha, e continua a ter, o internacionalismo como um alvo predileto. Antes que esse processo se consumasse, Marighella denunciava essas ameaças na imprensa do partido, reivindicava a legitimidade do PCB e a importância de defender a democracia. Mais uma vez recorreu a Lenin: "quanto 
maior é a liberdade política em um país, quanto mais sólidas e democráticas são suas instituições representativas, tanto maior facilidade tem as massas populares para orientar-se na luta dos partidos e aprender a política. Isto é, a desmascarar o logro e encontrar a verdade" (MARIGHELLA, 1946 apud PINHEIRO; FERREIRA, 2013, p. 40-41) ${ }^{5}$.

A Revolução de Outubro de 1917, que abalou o mundo (REED, 1982), contou com participação ativa das mulheres em suas mobilizações. Uma vez derrubado o tzarismo, a emancipação feminina foi contemplada em políticas públicas que, certamente, assombrava o patriarcado. Wendy Goldman relata que "em 1919, em meio à guerra civil, o Partido Comunista estabeleceu o Jenotdiél ou Departamento de Mulheres" (GOLDMAN, 2017, p. 64). Segundo essa autora, "o estabelecimento do Jenotdiél foi um evento sem precedentes na história humana: trata-se da primeira organização de massas criada por mulheres para a promoção dos próprios interesses em um contex to revolucionário" (Ibidem, p. 64). Algumas conquistas foram alcançadas tendo como base: "a socialização do trabalho doméstico, a plena igualdade entre gêneros, a livre união e o definhamento da família" (Ibid., p. 63). A criação de creches, lavanderias e refeitórios públicos incidiram, diretamente, no cotidiano. O Departamento de Mulheres estava vinculado diretamente ao Comitê Central do Partido Comunista da Rússia e funcionava como um órgão participativo realizando assembleias locais. Goldman notifica que "em 1920, o Estado soviético fez seguir a promulgação do Código da Família de outro decreto sem precedentes e tornou-se o primeiro país do mundo a legalizar o aborto" (Ibid., p. 68). Tais medidas, não foram acatadas sem conflito. E, nos anos de 1930, ocorreu o que a autora definiu como "reversão completa" da concepção de família russa: "crianças acima de doze anos que cometessem crimes seriam julgadas como adultos. Os pais tornaram-se imputáveis por ações criminosas de seus filhos. A lei de [1936] também tornava a proibir o aborto, a não ser que a saúde estivesse em risco e criminalizou a assistência ao aborto" (Ibid., p. 72 e 73). O direito ao divórcio também foi limitado e ocorreu "o retorno da criminalização da homossexualidade em 1934" (ALI, 2017, p. 87)

Clara Zetkin, feminista e dirigente comunista alemã, relembrou, nas "Notas de Meu Diário. Lênin, tal como era" (ZETKIN, 1956) ${ }^{6}$, logo após a morte do líder bolchevique, um debate travado entre eles sobre a emancipação feminina. Para Zetkin, "é desnecessário dizer que ele considerava a plena igualdade social da mulher como um princípio indiscutível do comunismo" (Ibidem). Sobre o direito ao divórcio, relatou a posição de Lenin: "a decadência, a putrefação, a lama do casamento burguês, com as suas dificuldades de dissolução, com a liberdade para o marido e a escravidão para a mulher, a mentira infame da moral sexual e das relações sexuais enchem os melhores homens de um desgosto profundo" (Ibid.).

O deputado Carlos Marighella, em um dos seus mais conhecidos discursos - "A Religião, O Estado, A Família" -, enfrentou o tema do direito ao divórcio como fundamental na sociedade brasileira. Marighella conjugou o mandato com a edição da Revista Problemas, onde publicou o referido discurso. Antes de chegar ao ponto central, fez uma ampla explanação sobre as implicações do Estado e da religião na sociedade. Em seguida, recorreu a Lenin no seguinte item: 
A religião é um aspecto da opressão espiritual que pesa sempre e por toda a parte sobre as massas populares submetidas pelo trabalho perpétuo em proveito de outrem, pela miséria e a solidão. A fé em uma vida melhor, no além, nasce inevitavelmente, da impotência das classes exploradas contra os exploradores tanto quanto a crença nas divindades, nos diabos, nos milagres etc. nasce da impotência do selvagem em luta contra a natureza (MARIGHELLA, 1947 apud PINHEIRO; FERREIRA, 2013, p.46)7.

Num país de forte tradição cristã, patriarcal e sexista, não deixa de ser provocadora a comparação de Marighella. Ele acabou perdendo a batalha pela aprovação do divórcio, mas não perdeu a oportunidade de provocar. Fez menção ao fato correlacionando com a Rússia comunista, mas numa perspectiva que demonstra desconhecimento com as reversões acima citadas e cometendo alguns deslizes:

$\mathrm{Na}$ União soviética, também, quando se estabeleceu o divórcio, milhares e milhares de casos surgiram repentinamente; mas eram remanescentes do capitalismo que havia sido destruído. Logo depois, quando se regularizou a situação, o divórcio, na União Soviética, vem diminuindo, porque, na realidade, o que o homem aspira é à monogamia e não as condições estabelecidas, pela opressão negra do capitalismo (Ibidem, p. 59).

O tom bem-humorado como Marighella abordava certos temas é uma das suas facetas. Vale a pena conferir um trecho do discurso:

A Igreja Católica nega o divórcio precisamente porque sabe o que o adultério é tão inevitável quanto a morte, e o que não se pode remediar remediado está. (...) Fora de dúvida, entretanto, é que as mulheres vencidas conseguiram, pelo menos, enfeitar as respeitáveis cabeças de seus maridos, única vingança que podem tirar, até que transformemos esta sociedade (Ibid., p. 56).

$\mathrm{Na}$ linha política do PCB - com raras exceções - predominou uma forte tendência pela aliança com a burguesia brasileira e sua fração nacional. Marighella, em outro artigo da Revista Problemas, debateu o período pós-guerra e criticou a penetração do imperialismo norte-americano no país. Ademais, inscreveu em seu texto: "marchamos, assim, para a unidade com a burguesia e em prazo tanto mais curto quanto mais firmemente soubermos levantar as reivindicações das massas e evitar o isolamento (MARIGHELLA, 1947 apud PINHEIRO; FERREIRA, 2013, p. 79)8. Nem por isso, Marighella deixaria de reconhecer certas debilidades do partido diante da persecutória legislação que levou a cassação. Marighella, timidamente, apresentava algumas observações críticas:

Não organizamos o movimento de massas; nosso movimento sindical é muito débil. E nisso residem as causas dos golpes que a reação tem aplicado contra a democracia entre nós. (...) desde o fechamento do Partido, em maio, já nossa orientação deveria ter sido mais aprofundada. O fato é que a democracia no Brasil - com aliás o próprio Prestes já o afirmara tantas vezes - não passava de uma democracia formal (MARIGHELLA 1948 apud PINHEIRO; FERREIRA, 2013, p. 85-86)9.

Com os comunistas na ilegalidade, Marighella e os comunistas foram obrigados a atuarem na clandestinidade. O partido lançaria o Manifesto de Agosto, em 1950, defendendo a libertação nacional pela via armada. Esta mostrou-se mais uma retórica do que uma ofensiva realista. Marighella retorna à São Paulo e lidera a Greve dos 300 mil, ocorrida em 1953. Em seguida, foi enviado a China e a ex-União Soviética. Para Mário Magalhães, “o envio de Marighella à China não fora sinal de prestígio, mas um passaporte para o exílio após o sucesso da greve de 1953” (MAGALHÃES, 2012, p.223). Posteriormente, o próprio Marighella explicou essa situação numa entrevista: “fui a China em 1953-1954. Foi o Partido que 
me mandou. Eu começava, na época, a contestar sua linha e era o mais forte candidato às eleições internas para o Estado de São Paulo. Então me afastaram, por algum tempo" (MARIGHELLA, 1969 apud CARONE, 1984, p. 66 $)^{10}$. Mais adiante, após seu retorno ao Brasil, em participação direta no IV Congresso do PCB, ocorrido no ano de 1954, assinalava: "são ainda pequenos os nossos esforços para penetrar no campo e criar a aliança operário-camponesa, base sobre a qual se desenvolve a Frente Democrática de Libertação Nacional" (MARIGHELLA, 1955 apud PINHEIRO; FERREIRA, 2013, p. 145) ${ }^{11}$. As críticas registradas de forma incipiente ainda não colidiam com a linha política partidária. Inclusive, o principal editor da Revista Problemas, quando esse periódico completava um ano e meio de existência, já havia afirmado em meados de 1948:

Como revista teórica, Problemas trouxe inegável contribuição à frente ideológica no Brasil, ajudando a desenvolver e elevar o nível ideológico dos combatentes da causa democrática e anti-imperialista. Não o fez, porém, sem deixar de se situar, com o mais estrito rigor, dentro daquele lema de Stalin, tão bem difundido nos Fundamentos do Leninismo, segundo o qual a "teoria deixa de ter objetivo quando não se acha vinculada à prática revolucionária, do mesmo modo que a prática é cega se a teoria revolucionária não ilumina o seu caminho" (MARIGHELLA, 1948 apud PINHEIRO; FERREIRA, 2013, p. 101) $)^{12}$

E no IV Congresso do partido, em 1954, Stalin é citado novamente e a referência entre a ação e teoria revolucionária vêm à tona: "como ensina Stalin, nosso Partido deve conservar todos os atributos de um autêntico partido de ação e não de um partido de espera contemplativa. Unicamente nesse caso, o Partido não desaproveitará, não deixará passar o momento das ações decisivas nem se deixará pilar desprevenido pelos acontecimentos" (MARIGHELLA, 1955 apud PINHEIRO; FERREIRA, 2013, p. 146) ${ }^{13}$.

Em 1944, preso político na Colônia de Dois Rios, na Ilha Grande, em Angra dos Reis, Marighella escreveu um poema em homenagem a derrota imposta pela ex-União Soviética ao regime nazista: "hoje o mundo respira mais livre,/eu peço licença pra dizer simplesmente:/ - Você, sim, que é muralha, União Soviética" (MARIGHELLA, 1944)14. Em 1956, dois anos após Stalin ser citado por Marighella no congresso dos comunistas brasileiros, o XX Congresso do Partido Comunista da União Soviética (PCUS) detonava o culto à personalidade a Stalin: foram revelados os crimes cometidos durante o período em que esteve no poder na ex-União Soviética. Jorge Amado, que também foi deputado pelo PCB, destrincha como receberam a informação: "eu me recordo de quando caiu sobre nós a verdade sobre Stalin - que era nosso 'pai', 'o pais dos povos', aquele que tinha nos 'salvo' do milênio hitlerista que iria dominar o mundo" (AMADO, 1999, p. 388). Um ano depois da denúncia, houve uma reunião da Comissão Executiva do PCB. O escritor baiano descreve a reação de Marighella, que era suplente da Comissão Executiva: "todos nós fomos a tribuna. Eu não era membro do Comitê Central, estava como convidado. E Marighella começou a falar, e de repente, os soluços se irromperam e ele começou a chorar e não pode sequer concluir seu discurso. (...) Quando chorou, Marighella foi digno dos homens dignos" (Ibidem, p. 389).

Marighella participou, ativamente, da reorganização do PCB. Prevaleceu sua dedicação ao partido. Com as denúncias, uma inevitável luta interna se abateu sobre os comunistas. Nesse processo, ele 
passou a representar a direção partidária junto à Comissão Nacional de Finanças. Em agosto de 1957, numa tensa reunião do Comitê Central, Marighella e outros dirigentes ganharam espaço no partido:

Mário Alves, Giocondo Dias e Carlos Marighella são guindados à Comissão Executiva. Marighella, que a integra pela primeira vez, passa a integrar também o Secretariado do Comitê Central - que era na verdade o todo-poderoso organismo que conduzia o partido no dia-a-dia - ao lado de Prestes e Giocondo Dias. Em meio à crise, ele ascendeu rapidamente. Passou a tesoureiro do Comitê Central e a um dos três mais importantes do partido (JOSÉ, 1997, p.189).

Mas, essa ascendência - como veremos adiante - não o acomodou. Mudanças significativas na conjuntura internacional e nacional, com destaque a Revolução Cubana (1959) e à implantação da Ditadura Empresarial Militar (1964-1985), trouxeram novos elementos. Antes que esses fatos se consolidassem, é importante recuperar um tema da Declaração de Março de 1958, documento central do partido comunista nesse período. Dois anos depois de ratificada e aprovada no V Congresso do partido, esta declaração revela a linha política defendida:

As transformações que a sociedade brasileira reclamava - a revolução brasileira seriam realizadas pela via pacífica; (...) o documento não modificava a visão da revolução em etapas. (...) A Revolução no Brasil, por conseguinte, não é ainda socialista, mas anti-imperialista e antifeudal, nacional e democrática (...) (Ibidem, p.191-192).

\section{Marighella e o "encontro" com alguns referenciais leninistas}

Foi a partir da sua quarta e última prisão que Marighella intensificou suas críticas ao PCB. Transcorrido um mês e nove dias do golpe instalado em 1964, Carlos Marighella foi baleado e preso num cinema situado no bairro da Tijuca. Ficou detido entre 9 de maio e 31 de julho, quando conseguiu um habeas corpus impetrado pelo advogado Sobral Pinto. O episódio foi narrado no livro, "Por que resisti à prisão?", publicado no ano seguinte. Marighella detalhou a resistência no enfrentamento com os policiais, denunciava as arbitrariedades da ditadura e tecia avaliações sobre o PCB. A propalada aliança com a burguesia foi criticada em várias passagens: "o marxismo - dizia Lenin - é a análise concreta da concreta situação, (...) não cabe aos marxistas manter ilusões na liderança da burguesia nacional, como aconteceu em relação à fração da burguesia que ocupava o poder nos idos de março” (MARIGHELLA, 1965, p.103). Ou ainda, "a liderança da burguesia nacional é sempre débil e vacilante” (Ibidem, p.147). Recordemos que a linha política do partido comunista, aprovada no V Congresso, mantinha a aliança com a burguesia como um de seus objetivos. Assim como, a tática de enfrentamento pacífico.

A Revolução Cubana foi citada duas vezes. Marighela tinha consciência da complexidade daquele processo revolucionário e a originalidade daquele movimento:

A lição da experiência de Cuba não está em localizar as nossas "serras maestras" ou em produzir cópias de situações, mas em saber apreciar a validez das teses táticas e princípios revolucionários postos em ação para decidir da vitória de um povo como o cubano. Teses táticas e princípios que sempre assumem características próprias, quando aplicados à realidade concreta deste ou daquele país da América Latina (Ibid., p.142). 
Se não cabiam aos marxistas manterem ilusões na aliança com a burguesia, quais seriam os setores que deveriam compor uma frente de oposição à ditadura? Já no livro editado em 1965, Marighella apontava a necessidade de aprofundar o trabalho de base no setor rural. Em 1966, em novo ensaio, avança nessa temática:

O trabalho mais importante, aquele que tem caráter prioritário, é a ação no campo, o deslocamento das lutas para o interior do país, a conscientização do camponês. No esquema estratégico brasileiro, o pedestal da ação do proletariado é o trabalhador rural. A aliança dos proletários com os camponeses é a pedra de toque da revolução brasileira. Ela significará um grande passo à frente - ou seja a substituição do esquema burguesia-proletariado por um plano estratégico marxista. Nesse plano, o camponês e o campo desempenharão o papel decisivo no apoio à luta das massas urbanas (MARIGHELLA, 1979, p.62).

Como citado acima, Marighella reproduzia um parâmetro do partido: “o proletariado não pode seguir uma tática qualquer. A tática que não convier à conquista dos objetivos estratégicos da revolução anti-imperialista e antifeudal, nacional e democrática, deve ser repelida” (Ibidem, p.71). Em princípio, esta afirmação induz a compreensão de que Marighella construía uma ruptura com o PCB, mas a estratégia seria mantida.

Em dezembro do mesmo ano, Marighella escreveu a "Carta à Executiva” repreendendo a posição do partido em relação ao governo Jango e, com o avanço da ditadura, a insistência no caminho pacífico. Ele emendaria que o partido:

Parece não ter compreendido Lenin quando em "Duas Táticas" afirma que "os grandes problemas da vida dos povos se resolvem pela força". Em outra parte, falando sobre a vitória, acrescenta Lenin que esta "deverá apoiar-se inevitavelmente na força armada das massas, na insurreição", e não em tais ou quais instituições criadas "por via legal” e "pacífica” (MARIGHELLA, 1979, p.93)

Ao mencionar Lenin, Marighella incorreu numa omissão que merece ser destacada. Lenin escreveu o seguinte: "as grandes questões da liberdade política e da luta de classes são resolvidas em última análise unicamente pela força e nós devemos preocupar-nos com a organização e preparação desta força e com o seu emprego ativo, não somente defensivo mas também ofensivo" (LENINE, 1986, p. 392). É necessário contextualizar a publicação do livro "Duas Táticas da Social-Democracia na Revolução Democrática”. Esta obra, de 1905, retrata uma acirrada polêmica entre Lenin e os mencheviques diante da massivas greves e mobilizações políticas que sacudiram a Rússia, levando a autocracia tzarista a convocar o parlamento (Duma) e a permitir a atuação de alguns partidos políticos. Nota-se, que foram criados os Sovietes, conselhos de representantes dos trabalhadores; que seriam retomados com toda força em 1917. Lenin, numa reedição de 1907, explicou o roteiro de seu escrito:

Aqui expõem-se, já de um modo sistemático, as fundamentais divergências táticas, com os mencheviques; as resoluções do III Congresso do POSDR [Partido Operário SocialDemocrata Russo], que teve lugar na Primavera em Londres (congresso dos bolcheviques), e da conferência dos mencheviques em Genebra, formalizaram de modo completo estas divergências e levaram-nos à discrepância radical quanto à apreciação de toda a nossa revolução burguesa do ponto de vista das tarefas do proletariado " (Ibidem, p. 715). 
No item 6, "De que lado ameaça o proletariado o perigo de se ver com as mãos atadas na luta contra a burguesia inconsequente", o revolucionário bolchevique se deteve aos desafios imposto naquela conjuntura específica. Vale alongar a citação:

"A vitória decisiva da revolução sobre o tsarismo" é a ditadura revolucionária democrática do proletariado e do campesinato. (...) E esta vitória será precisamente uma ditadura, isto é, deverá apoiar-se inevitavelmente nas forças das armas, nas massas armadas, na insurreição e não em tais ou tais instituições criadas "pela via legal”, "pacífica”. Só pode ser uma ditadura porque a realização das transformações imediatas e absolutamente necessárias para o proletariado e o campesinato provocará uma resistência desesperada tanto por parte dos latifundiários como da grande burguesia e do tsarismo. Sem ditadura será impossível esmagar esta resistência, rechaçar as tentativas contrarrevolucionárias. Mas não será, naturalmente, uma ditadura socialista, mas uma ditadura democrática. Esta ditadura não poderá tocar (sem toda uma série de graus intermediários de desenvolvimento revolucionário) os fundamentos do capitalismo. Poderá, no melhor dos casos, efetuar uma redistribuição radical da propriedade da terra a favor dos camponeses, implantar uma democracia consequente e completa indo até a república, extirpar não só da vida do campo mas também da fábrica todos os traços asiáticos, servis, iniciar uma melhoria séria na situação dos operários, elevar o seu nível de vida e, finalmente, last but not least [o último mas não o menos importante] levar o incêndio revolucionário à Europa " (Ibid., p. 411).

Ao comparar a citação utilizada por Marighella com a de Lenin, percebe-se que o comunista baiano se esquivou do debate acerca da ditadura do proletariado e do campesinato. Tal omissão é significativa em duas direções: de certa forma, indica que Marighella não reivindicava a ditadura do proletariado; de outro modo, o que de fato queria, era defender a guerrilha como tática de enfrentamento e derrota da ditadura. Novamente, evocou um trecho do texto de Lenin intercalado pela reafirmação da guerrilha:

"É verdade que nossa influencia, a dos social-democratas (quer dizer, as dos comunistas), sobre a massa do proletariado ainda é muito insuficiente; a influência revolucionária sobre a massa camponesa é insignificante; a dispersão, a falta de desenvolvimento, a ignorância do proletariado e sobretudo dos camponeses, ainda são terrivelmente enormes". "A Revolução, porém, aglutina as forças com rapidez. $e$ as instrui com a mesma velocidade. Cada passo dado no seu desenvolvimento desperta a massa e a atrai com uma força irresistivel para o programa revolucionário, o único que exprime de um modo consequente e completo os seus verdadeiros interesses, seus interesses vitais". (LENINE apud MARIGHELLA, 1979, p. 93) ${ }^{15}$

Há no Brasil forças revolucionárias internas capazes de resistir à ditadura e ir à luta. E é verdade que o pensamento leninista brota por toda parte onde o proletariado faz sentir sua influência (MARIGHELLA, 1979, p.93).

Em texto de 1967, as teses que embasavam o VI Congresso do PCB foram debatidas e aprofundadas. Sobre a tática do partido diante da ditadura, Marighella afirmou: "o máximo previsto nessa tática é a combinação de formas elementares e legais de luta com a luta armada. A insurreição armada e a guerra civil são admitidas quando impostas ao povo pela ditadura, com o apoio do imperialismo norteamericano" (Ibidem, p. 114-115). A tese do partido foi atacada como espontaneísta: "apregoa a derrota da ditadura como consequência de uma explosão espontânea das massas ou por efeito das contradições entre as classes dominantes" (Ibid., p.115). Para Marighella, a tática para enfrentar a ditadura tinha centralidade na guerra de guerrilhas, não havia espaço para os caminhos institucionais. E para embasar a sua crítica ao PCB, recorreu a Lenin: 
A propósito de tais questões seria útil reler agora "Que Faz̧er" e "Duas Táticas da SocialDemocracia na Revolução Democrática". Nesta última obra Lenin diz que o erro fundamental é render culto ao espontaneísmo, pois quanto maior e mais poderoso seja o auge espontâneo das massas, tanto mais se exige elevar a consciência do partido. Sem isso não se pode dirigir todo o movimento. $\mathrm{E}$ de explosões espontâneas nada se pode esperar, se não há liderança da vanguarda do proletariado (Ibid., 115).

O caminho pacífico era, definitivamente, recusado pelo futuro líder da ALN. Entre 31 de julho a 10 de agosto de 1967, realizou-se em Cuba a Conferência da Organização Latino-Americana, (OLAS), contrariando as orientações do Partido Comunista, Marighella foi a Cuba. Não participou, diretamente, do evento. Entretanto, não perdeu a oportunidade de - em entrevistas e escritos - intensificar seu distanciamento com o partido comunista e reafirmar a adesão à luta armada. Além disso, firmou acordos com o comando revolucionário cubano de futuros treinamentos de guerrilheiros naquele país. Porém, Marighella jamais admitiria qualquer intervenção de Cuba sobre os caminhos da guerrilha no Brasil. A ruptura se consolidava e Marighella apontou:

\begin{abstract}
Até então a experiência das revoluções de caráter marxista-leninista assentara suas bases na transformação da guerra anti-imperialista mundial em guerra civil pela tomada do poder. Esta situação, com suas indispensáveis variantes, assinalou o desenvolvimento da história dos povos pelo menos durante quatro décadas, a partir do triunfo da Grande Revolução Socialista de Outubro. A revolução cubana, como parte integrante da revolução socialista mundial, trouxe ao marxismo-leninismo um novo conceito: o da possibilidade de conquistar o poder através da guerra de guerrilhas, e expulsar o imperialismo quando não há guerra mundial e não se pode, portanto, transformá-la em guerra civil (Ibidem, p. 117).
\end{abstract}

\title{
Conclusão
}

É preciso reafirmar a autonomia do PCB diante dos desafios conjunturais da sociedade brasileira. Foram anos atuando na ilegalidade, sufocado pelas perseguições que revelam a face explícita do bloco dominante e os mecanismos coercitivos da autocracia burguesa. A própria trajetória de Marighella fornece pistas nesse sentido. Esse partido cumpriu um papel histórico de relevância e, atualmente, reformulado não se rende ao fetiche neoliberal.

Contudo, como procuramos demonstrar, Marighella - em parte de sua trajetória no partido "dialoga" com Lenin pressionado pelas diretrizes stalinistas e pela linha política adotada. Nesse sentido, houve mais "desencontro" do que "encontro" com as premissas leninistas.

De outro modo, a ruptura de Carlos Marighella com o PCB e a formação da ALN é objeto de análise de vários autores. A nós, interessa o tema do foquismo e a aproximação com o "etapismo". Com a ressalva que o debate é mais amplo e aqui não se encerra. O foquismo é um referencial teórico, com base no livro "A revolução na revolução", de Régis Debray, que teve a pretensão de sistematizar o processo revolucionário cubano a partir da suposta teoria do foco revolucionário (DEBRAY, 1967). Por esse caminho, bastaria um pequeno núcleo de combatentes guerrilheiros na área rural, um pequeno motor, para aglutinar e galvanizar o processo revolucionário, entre outros postulados. 
Gorender afirmou que na ALN “o primeiríssimo princípio é o da ação. É a ação que faz a organização e a desenvolve. Ação que significa violência revolucionária, luta armada, guerrilha. A ação cria tudo a partir do nada, do zero (repete-se a sentença de Fidel Castro). Daí decorre a atitude antiteoricista" (GORENDER, 1998, p.105). Nesse sentido, “o foquismo se mantém, na medida em que a guerrilha começa do zero, dissociada de qualquer movimento de massas, e incorpora a função de vanguarda política" (Ibidem, p.107). Essa aproximação da elaboração de Marighella com o foquismo é também analisada por outro autor: "o que se verifica é uma 'releitura atualizada', como preferiram seus autores [Carlos Marighella e Régis Debray], ou uma revisão do leninismo, como preferiam seus críticos. Em lugar do partido conspirativo, a organização guerrilheira, em lugar do golpe revolucionário, a guerra de guerrilhas" (FERREIRA, 1999, p. 237). Além dessas caracterizações, Gorender e Muniz Ferreira concordam que a ALN herdou a concepção "etapista" da revolução defendida pelo PCB. A exposição de Gorender não deixa dúvidas: "a ALN herdou do PCB a teoria das duas etapas da revolução; colocou a libertação nacional como primeiro objetivo, ao qual se seguiria o do poder socialista" (GORENDER, 1998, p.107).

A inflexão de Marighella, na década de 1960, quando passou a defender a guerrilha rural e urbana, embora ainda mediado por tradições de sua formação política, evidenciam um "encontro" com premissas dos textos de Lenin de modo mais autônomo: Marighella passou defender a ação revolucionária pautada pela insubordinação à aliança com a burguesia.

É fato reconhecido que a ALN foi dizimada pela Ditadura Empresarial-Militar. Como também é importante afirmar que a concepção da guerrilha preconizada por Marighella foi alterada diante desse enfrentamento. O que não invalida debater seus avanços e retrocessos naquela conjuntura.

Propomos ir além da construção de uma narrativa que associa Marighella e a opção pela luta armada com a teoria do foco revolucionário. Assim como, é preciso problematizar a continuidade do "etapismo" na ALN. A crítica a aliança com a burguesia é fundamental, pois sugere que a libertação nacional - consigna da organização liderada por Marighella - não tinha o mesmo caráter e fundamento que o PCB conduziu por longo período. É compreensível que a reivindique. Mas, ao destacar o caráter reacionário da burguesia, não havia mais espaço de conciliação.

Por fim, é importante realçar que não desconhecemos que a concepção de organização que Marighella passou a defender na ALN é, inexoravelmente, oposta a concepção de partido político. O que evidencia uma recusa a concepção leninista de partido. Por outro lado, reduzir essa concepção ao foquismo, subalterniza a sua contribuição para a desburocratização e maior horizontalidade para os organismos coletivos que continuam o desafio de supressão do capital. Este, certamente, é um legado dos mais potentes de Carlos Marighella.

\section{Referências:}

AMADO, Jorge. O homem que ria e chorava. In NOVA, Cristiane. NÓVOA, Jorge (orgs.). Carlos Marighella: o homem por trás do mito. São Paulo Editora UNESP, 1999, (PRISMAS), p. 381-392. 
ALI, Tariq. As mulheres de outubro. In JINKINGS, Ivana \& DORIA, Kim (Orgs.). 1917: o ano que abalou o mundo. São Paulo: Boitempo: ED. SESCSP, 2017, p. 79-90.

CARONE, Edgard. Movimento operário no Brasil (1964-1984). São Paulo: Difel, 1984.

DEBRAY, Regis. Revolução na Revolução. Havana: Casa de Lãs Américas, 1967

DEMIER, Felipe. A lei do desenvolvimento desigual e combinado de Trotsky e a Revolução Russa. In DEMIER, Felipe \& MONTEIRO, Marcio Lauria (orgs.). 100 anos depois: a Revolução Russa de 1917. Rio de Janeiro: Mauad X, 2017.

FERREIRA, Muniz. Radicalizando a política: a crítica de Marighella às posições do PCB no imediato pós 64. São Paulo: Revista Novos Rumos, V. 50, $\mathrm{n}^{\circ}$ 2, 2013, p.1-11. Disponível em: http://www2.marilia.unesp.br/revistas/index.php/novosrumos/issue/view/251. Último acesso em maio de 2020 .

FERREIRA, Muniz. Carlos Marighella: revolução e antinomias. In NOVA, Cristiane. NÓVOA, Jorge (orgs.). NOVA, Cristiane. NÓVOA, Jorge (orgs.). Carlos Marighella: o homem por trás do mito. São Paulo Editora UNESP, 1999, (PRISMAS), p. 221-256.

GOLDMAN, Wendy. A libertação das mulheres e a Revolução Russa. In JINKINGS, Ivana \& DORIA, Kim (orgs.). 1917: o ano que abalou o mundo. São Paulo: Boitempo: ED. SESCSP, 2017, p. 63-76.

GORENDER, Jacob. Combate nas trevas. São Paulo: Ática, 1998.

JOSÉ, Emiliano. Carlos Marighella: o inimigo público número um da ditadura militar. São Paulo: Sol \& Chuva, 1997.

KONDER, Leandro. A derrota da dialética: a recepção das ideias de Marx no Brasil, até o começo dos anos 30. São Paulo: Expressão Popular, 2009.

LENIN, Vladimir Ilitch. O imperialismo: fase superior do capitalismo. São Paulo: Centauro, 2010.

LENIN, Vladimir Ilitch. O socialismo e a emancipação da mulher. Rio de Janeiro: Editorial Vitória, 1956. Disponível em: https://www.marxists.org/portugues/zetkin/1920/mes/lenin.htm, último acesso em junho de 2020

LENINE, Vladimir Ilitch. Obras Escolhidas. São Paulo: Alfa Ômega, 1986.

MAGALHÃES, Mário. Marighella: o guerrilheiro que incendiou o mundo. São Paulo: Cia das Letras, 2012.

MARIGHELLA, Carlos. Poemas: Rondó da Liberdade. São Paulo: Brasiliense, 1994.

MARIGHELLA, Carlos. Por que resisti à prisão. Rio de Janeiro: Brasiliense, 1965.

MARIGHELLA, Carlos. A crise brasileira. In MARIGHELLA, CARLOS. Escritos de Carlos Marighella. São Paulo: Editorial Livramento, 1979, p.49-88.

MARIGHELLA, Carlos. Carta à Executiva. In MARIGHELLA, CARLOS. Escritos de Carlos Marighella. São Paulo: Editorial Livramento, 1979, p. 89-98.

MARIGHELLA, Carlos. Ecletismo e marxismo. In MARIGHELLA, CARLOS. Escritos de Carlos Marighella. São Paulo: Editorial Livramento, 1979, p. 113-116.

MARIGHELLA, Carlos. Algumas questões sobre a guerrilhas no Brasil. (Publicado no Jornal do Brasil, edição de 05 de setembro de 1968) - Havana, outubro de 1967. In MARIGHELLA, CARLOS. Escritos de Carlos Marighella. São Paulo: Editorial Livramento, 1979, p. 117-130.

MARX, Karl \& ENGELS, Friedrich. Obras escolhidas. São Paulo: Alfa Ômega, s/d.

MATTOS, Marcelo Badaró. Sete notas introdutórias como contribuição ao debate da esquerda socialista no Brasil. Rio de Janeiro: Consequência, 2017.

NOVA, Cristiane. NÓVOA, Jorge (orgs.). Carlos Marighella: o homem por trás do mito. São Paulo Editora UNESP, 1999, (PRISMAS). 
PINHEIRO, Milton \& FERREIRA Muniz (Orgs.). Escritos de Marighella no PCB. São Paulo: ICP; Rio de Janeiro; FDR, 2013.

PRESTES, Anita Leocádia. A Revolução Russa e a Fundação do Partido Comunista no Brasil. In JINKINGS, Ivana \& DORIA, Kim (Orgs.). 1917: o ano que abalou o mundo. São Paulo: Boitempo: ED. SESCSP, 2017, p. 137-150.

REED, John. Reds: dez dias que abalaram o mundo. São Paulo: Global Editora, 1982.

SILVA JÚNIOR, Edson Teixeira da. Um combate ao silêncio: a ALN (Ação Libertadora Nacional) e a repressão política. Tese de doutorado. Programa de Pós-Graduação em História (PPGH). Niterói: Universidade Federal Fluminense (UFF), 2005.

SILVA JÚNIOR, Edson Teixeira da. Carlos: a face oculta de Marighella. São Paulo: Expressão Popular, 2009.

VIANNA, Marly de Almeida Gomes. Revolucionários de 35: sonho e realidade. São Paulo: Companhia das Letras, 1992.

ZETKIN, Clara. Notas de meu diário. Lênin tal como era. In LENIN, V. I. O socialismo e a emancipação da mulher. Rio de Janeiro: Editorial Vitória, 1956. Disponível em: https://www.marxists.org/portugues/zetkin/1920/mes/lenin.htm. Último acesso em junho de 2020.

\footnotetext{
Notas

1 Doutor em História pela Universidade Federal Fluminense (UFF). Professor Associado I do Departamento Interdisciplinar de Rio das Ostras (RIR) no curso de Serviço Social da UFF. Membro do Núcleo de estudos e pesquisas afro-brasileiro (NEAB). Currículo Lattes: http://lattes.cnpq.br/9702837899322401. Orcid: https://orcid.org/0000-0003-2871-1739. E-mail: edsonteixeirauff@gmail.com.

2 O Partido Comunista do Brasil foi fundado em 25 de março de 1922, tendo como sigla PCB. Afim de se adequar à legislação nacional, em 1960 a organização alterou o nome para Partido Comunista Brasileiro. Em 1962, a antiga denominação seria adotada por dissidentes com a sigla PCdoB (MATTOS, 2017, p.17).

3 Trata-se do artigo de Carlos Marighella "A Assembleia Constituinte e o Partido Comunista" publicado no periódico A Classe Operária, Rio de Janeiro, 16/3/1946, conforme referência citada. O trecho destacado em itálico é uma citação de Carlos Marighella de: ENGELS, Friedrich (Introdução). As lutas de classes da França (1895). In MARX, Karl \& ENGELS, Friedrich. Obras escolhidas. São Paulo: Alfa Ômega, s/d., p.103.

${ }^{4}$ Trata-se do artigo de Carlos Marighella "O $1^{\circ}$ de maio e a Luta Pela Paz" no periódico A Classe Operária, Rio de Janeiro, n8, de $1^{\circ}$ de maio de 1946 , conforme referência citada.

5 Trata-se do artigo de Carlos Marighella "A Democracia e a Legalidade do PCB” no periódico A Classe Operária, Rio de Janeiro, 25/5/1946, conforme referência citada.

${ }^{6}$ Disponível em: https://www.marxists.org/portugues/zetkin/1920/mes/lenin.htm, último acesso em junho de 2020. Trata-se da edição eletrônica, no respectivo site citado, de: LENIN, V. I. O socialismo e a emancipação da mulher. Rio de Janeiro: Editorial Vitória, 1956. O texto de Clara Zetkin está disponível como apêndice.

${ }^{7}$ Trata-se de discurso pronunciado no parlamento por Carlos Marighella intitulado "A Religião, O Estado, A Família" em 4 de julho de 1946. Posteriormente, esse discurso foi publicado no periódico vinculado ao PCB: Problemas - Revista Mensal de Cultura Política $\mathrm{n}^{\circ}$ 2, setembro de 1947, conforme referência citada.

8 Trata-se de artigo de Carlos Marighella intitulado "Nossa Política”, publicado no periódico Problemas - Revista Mensal de cultura Politica $\mathrm{n}^{\circ}$ 5, dezembro de 1947, conforme referência citada.

${ }_{9}^{9}$ Trata-se de artigo de Carlos Marighella intitulado "Nossa Política" publicado no periódico Problemas - Revista Mensal de Cultura Política n$^{\circ}$, janeiro de 1948 , conforme referência citada.

10 Trata-se de entrevista de Carlos Marighella a Conrad Dretz, Revista Front, novembro de 1969, Panfleto.

11 Trata-se de intervenção de Carlos Marighella no IV Congresso do PCB (1955) intitulada "O Programa do Partido, as experiências das eleições de 3 de outubro e as nossas tarefas para a campanha eleitoral de 1955", publicada no periódico Problemas - Revista Mensal de Cultura Politica no 64, dezembro de 1954 a fevereiro de 1955, conforme referência citada.

12 Trata-se de artigo de Carlos Marighella intitulado "Nossa Política" publicado no periódico Problemas - Revista Mensal de Cultura Política $\mathrm{n}^{\circ} 12$, julho de 1948 , conforme referência citada.

13 Trata-se da mesma intervenção citada, anteriormente, de Carlos Marighella no IV Congresso do PCB (1955).
} 
14 Trata-se do poema "Muralha" de 1944, de autoria de Carlos Marighella. Disponível em https://www.marxists.org/portugues/marighella/poemas.htm, último acesso em junho de 2020. Ver também: MARIGHELLA, Carlos. Poemas: Rondó da Liberdade. São Paulo: Brasiliense, 1994.

15 O trecho citado por Carlos Marighella, destacado em itálico, pode ser verificado em: LENINE, V.I. Obras Escolbidas. São Paulo: Alfa Ômega, 1986, p. 411 e 412.

Recebido em: 13.08 .2020

Aprovado em: 25.09 .2020 